\title{
A Critical Discourse Analysis of Naming and Predication in Western News Coverage of the Egyptian January 25 and June 30 Protests
}

\author{
Hebatollah M. M. Hegazy \\ Alexandria University, Egypt
}

\begin{abstract}
This study aims at investigating how the use of language by the Western newspapers, namely, The New York Times (American) and The Guardian (British), has reflected differential ideological perspectives on the Egyptian January 25 and June 30 protests, particularly with regard to both Mubarak and Morsi, their governments, and their pro- and anti-regime protesters. Furthermore, the study examines the extent to which such differential ideological perspectives by the two news outlets have been consistently reflective of the official mainstream ideological views, and hence contributing to the notion of media as an ideological state apparatus (ISA). As for its analytical framework, the study has adopted Fairclough's (1995a) three-layer model of critical discourse analysis (CDA) and complemented it with van Dijk's (2000) ideological square in order to investigate the biased classification schemes created by Richardson's (2007) naming and predication which are two common textual features in Press discourse. The data comprises 32 news reports covering both Egyptian protests from the eruption of each to the downfall of both regimes (more specifically, from Jan. 25 to Feb. 11, 2011; and from Nov. 22, 2012 to July 3, 2013), focusing on five key events during each protest. The results have revealed that each newspaper's stance towards both protests has been ideologically-slanted and tremendously fed by its ownership/political affiliation, hence giving support to the notion of the media as an ISA.
\end{abstract}

Key words: critical discourse analysis, classification schemes, ideological square, ideological state apparatus, naming, predication

\section{Introduction}

The present study investigates the representation of the Egyptian January 25 and June 30 protests in the online versions of two Western newspapers; namely, The New York Times (American) and The Guardian (British). Both newspapers reflect the international perspective on both Egyptian protests, particularly the US' and the UK's. The current study examines the news reports covering the extended protests periods from 
the eruption of each to the ouster of the ruling president. The study uses the critical discourse analytical approach (CDA), particularly Fairclough's (1995a) three-layer model of CDA and van Dijk's (2000) ideological square to qualitatively analyze these news stories so as to uncover the above newspapers' ideological perspectives on the two protests, expose the frequently hidden power relationships, and highlight the influence of powerful groups and institutions in society on mainstream media, as held by a number of scholars (Althusser, 1971; Fairclough, 1994, 2003, 2006; Herman \& Chomsky, 2002; Richardson, 2007; van Dijk, 1991, 1993a, 1996, 1998, 2000).

Ashley and Olson (1998) as well as McQuail (1993) argued that media are given some responsibility whenever the stability of a society is at stake by war, crime, economic disaster, social protests, etc. Consequently, the media are more likely to support the legitimacy of the state and delegitimize the challenges of social orders. In correspondence to the assumptions of the aforementioned scholars, I argue that both examined newspapers' representation of the anti-Mubarak and anti-Morsi protests could be influenced by the official mainstream perspectives on both protests. However, the extent of such influence may vary based on the ownership/political affiliation of each newspaper. In fact, news reporting discourse, in particular, is chosen for analysis as it includes ideas and attitudes, not merely facts, as held by van Dijk (1991), despite being widely known as the most informative press discourse and hence supposedly impartial. Accordingly, the present study is expected to enhance the reader's knowledge and awareness of the manipulative nature of the news reporting discourse, thus promoting their critical abilities in reading newspapers. The present study aims to unveil the ideologies of the four newspapers towards both protests through examining their use of naming and predication, being two of the most common textual features of press discourse (Richardson, 2007), and their creation of biased classification schemes in representing both protests and their key social actors (i.e. both presidents, their governments, and their pro- and anti-regime protesters). It also investigates the extent to which such newspapers' ideologies have been steadily indicative of the official mainstream ideological perspectives and fed by their ownership/political affiliations, 
and hence giving support to the notion of media as an ideological state apparatus (ISA) in the sense of Althusser (1971).

To my best knowledge, comparing and contrasting the representation of the January 25 and June 30 protests in the American and British press received little attention. I have found only one study (ElNashar, 2014) handling such topic but only in association with the army's role in both protests, which is not the focus of the present study, in one American newspaper, using a CDA framework and a quantitative approach. Hence, the present study extends the scope of research by attempting to reveal how similar and/or different the ideologies of the American and British newspapers at issue are towards both protests and the main social actors involved, apart from the military institute. Such institute cannot be considered as belonging to the regime or its opponents during both protests since it had its own decisive role during both protests. Moreover, the current study also adds to the body of qualitative research on the Arab Middle East, particularly the issue of the Arab Spring, which contributes to bridging the gap between the linguistic, on the one hand, and the media, social, and political, on the other hand. Finally, the fact that both protests are recent historic events in Egypt lends an important element of timeliness and per se significance to the present study.

\section{Research Objectives}

The current study has the following objectives:

1. Unveiling the ideologies of both Western newspapers, The New York Times and The Guardian, towards the January 25 and June 30 Egyptian protests through examining the language employed by the four newspapers in representing both protests.

2. Unveiling the extent to which such newspapers' ideologies are steadily indicative of the official mainstream ideological stances and fed by their ownership/political affiliations.

\section{Research Questions}

The study purports to answer the following questions:

1. How does the use of language by the Western newspapers, namely, The New York Times (American) and The Guardian (British), reflect 
differential ideological perspectives on the Egyptian January 25 and June 30 protests, with respect to Mubarak and Morsi, their governments, and their pro- and anti-regime protesters?

2. To what extent are such ideological perspectives by the two news outlets regularly suggestive of the official ideological views, thus supporting the notion of media as an ISA?

\section{Theoretical Framework}

In the words of van Dijk (2001), CDA "studies the way social power abuse, dominance, and inequality are enacted, reproduced, and resisted by text and talk in the social and political context" (p. 353). CDA is concerned with highlighting the interrelationships between language, power, and ideology which may be hidden from people, as explained in the works of Fairclough (1989, 1992, 1995a), Fairclough and Wodak (1997), Hodge and Kress (1993), van Dijk (1980, 1983, 1991, 1995a, 1995b, 1996, 1997, 2001), and Wodak (1996). According to them, CDA aims at the following:

- Addressing social and political issues.

- Highlighting how power and dominance relations operate through language.

- Establishing the relationship between society and text which is mediated by order of discourse, i.e. structured sets of discursive practices associated with particular social domains.

- Revealing the ideologies underlying discursive and social structures.

In so doing, CDA explores which ideologies the controlling groups use to dominate the controlled groups through language within a society and this in particular what makes CDA a critical approach to discourse analysis (Rogers, 2004).

Ideology, as explained by van Dijk (1996), is "basic systems of shared social representations that may control more specific group beliefs (knowledge, attitudes), and influence models via the instantiation of such beliefs in concrete models of situations and experiences" (p. 7). Ideology, as regarded by Fairclough (2003), is a modality of power more than just being a coherent set of beliefs or values; it produces, reproduces, and 
challenges social relations of power, and hence representing the world. One important aspect of ideologies, according to van Dijk (2000), is manifested in the role they play in maintaining social group relations such as justifying and legitimizing domination, power abuse, and social inequality, on the one hand, and organizing opposition, resistance, and change, on the other. In this regard, ideologies, as van Dijk argued, represent social struggles; this necessitates representing the groups involved in such struggles in terms of group polarization, i.e. a representation of "Us", how we see ourselves, versus "Them", how we see others. In this concern, we represent ourselves positively as superior and represent others negatively as inferior. In other words, van Dijk's ideological square can help show how each examined newspaper identified the ingroup and the outgroup in the struggle between the regime and its opponents during both Egyptian protests through deemphasizing the negative actions of the ingroup and positive actions of the outgroup, on the one hand, while emphasizing the positive actions of the ingroup and negative actions of the outgroup, on the other.

It is important, accordingly, to shed light on Althusser's (1971) notion of the ISA in association with media discourse, particularly news reporting discourse due to its vital role in investigating such discourse as a form of social practice that may construct, foster, or challenge particular ideologies and power relations fed by the society's powerful elite people and institutions. One of the first to affirm that the media are not the voice of the average of normal person but rather are the voice of the powerful is Althusser in his Marxist account of ideology. He indicated that in order to produce and sustain dominance over society, a state must reproduce the conditions of production; otherwise, the state would lose dominance because state power is the exercise that guarantees the reproduction of relations of power within society. Althusser further emphasized that there are two types of apparatus that aim at reproducing the relations of power, namely, Repressive State Apparatus (RSA) and Ideological State Apparatus (ISA). He explained that the RSA is concerned with coercive power, i.e. hard power and includes the government, army, police, prisons, etc. The ISA, in which Althusser was particularly interested, is concerned with persuasive power, i.e. soft power and includes institutions 
that fall partly outside of state control but still serve to transmit the values of the state, such as the school, the Church, the legal system, the family, and the media. That is, as Althusser put it, the ISA aims at persuading the dominated groups to take the unequal power relations for granted and to regard them as being commonsensical and natural.

Mass media are a tool for representing ideological tendencies; they give access to hidden power relations (van Dijk, 1996). In the same vein, Herman and Chomsky (2002) underpinned that the mass media have a significant role as system-supportive propaganda. They argued that commercial media institutions form and define people's norms and beliefs according to the social, political, and economic interests dominating the state. In this sense, the media mobilize the public to support the social interests of the elite, and the dominant ideology of a society serves as its criterion for common sense and rational understanding (Herman \& Chomsky, 2002).

News is a representation of construction; it is not a value-free reflection of facts but rather reported from a particular perspective, being controlled by economic, political, and social institutions which express and implement their social meanings and values through language, as held by Fowler (1991). In line with Fowler, van Dijk (2000) elucidated that news discourse arises from the current social or political conflicts and struggles between individuals or social groups. Accordingly, each social group has its own version of social reality which is defended and expressed in such discourse, but the version that becomes dominant and naturalized is that of the powerful elites (van Dijk, 2000). In agreement with Fowler (1991) and van Dijk (2000), Richardson (2007) pointed out that newspaper discourse is a medium of power and acts in ideological ways. Journalists, in the discourse process suggested by CDA, act upon the world through maintaining or transforming social beliefs as well as producing and reproducing social realities (Richardson, 2007). Here emerges Richardson's description of news reports as being prejudiced, explicating that the media institutions policies direct them; otherwise, all the media outlets would relatively report all news in the same way. 
Therefore, it can be concluded that news reporting is not valueless, i.e. not neutral and, on occasion, is fundamentally biased owing to the fact that value judgments are integrated into the news making process at all stages, notably, newsgathering, news writing, story selection, editing, and presentation, as explained by Richardson.

Fairclough's (1995a) three-layer model of CDA is adopted, for it is one of the most comprehensive frameworks of CDA which was developed throughout his works (e.g. Chouliaraki \& Fairclough, 1999; Fairclough, 1989, 1992, 1993, 1995a, 1995b), and others. At the core of Fairclough's approach to CDA is a view of discourse at three levels, namely, textual analysis referred to as "a language text" ("description"), text production and consumption referred to as "discourse practice" ("interpretation"), and the wider social context around its production and consumption referred to as "sociocultural practice" ("explanation") (p. 97). Hence, as Fairclough maintained, his framework of CDA can be employed in investigating social issues like those tackled in press discourse, which is the focus of the present study.

As far as the description level of analysis is concerned, Fairclough (1995a) stated textual analysis involves the analysis of the way propositions are structured, combined and sequenced. He pointed out that language use is simultaneously constitutive of social identities, social relations, and systems of knowledge and beliefs. That is, the language used is selected and controlled to achieve specific social purposes, and the analyst may pay attention to any or all of the grammar, lexis, intonation, and cohesive devices used, as well as global meanings.

As for the interpretation level of analysis, it refers to the way that actual discourse is institutionally determined (Fairclough, 1995a). Indeed, text production and interpretation are embedded in institutional discourse practices and therefore mediate between the sociocultural practice (the area of context) and text. Fairclough argued that it is at the interpretation level that the implicit meanings underlying any given discourse are unveiled through revealing what people have in their mind such as their beliefs, ideologies, and knowledge of language. 
In the explanation level of analysis, Fairclough (1995a) underscored that discourse as social practice means that language is a social process. He explained that the social context of our lives, which includes all the elements both linguistic and non-linguistic, shapes the ways in which we use language; this provides the context for how we interpret and understand the world. In other words, discourse at the level of context involves the social conditions of the production and interpretation of meaning. Thus, the actual power of the text cannot be described unless reference is made to the wider social models of the world, as held by Fairclough. He highlighted that the analysis of such socio-cultural context of which a particular event is part may involve its immediate situational context, the wider context of institutional practices within which the event is embedded, or the yet wider frame of the society and culture.

In the present study, biased classifications schemes generated through the examined newspapers' use of two textual features, namely, naming and predication are explored. Classification schemes indicate how meanings are categorized in specific semantic domains (Fairclough, 1989). Fairclough explained that the classification scheme adopts two linguistic techniques: lexicalization and overlexicalization. The former refers to the choice of words which convey the ideology of writers and their evaluation of certain aspects (Fairclough, 1989). The latter is defined by Fairclough as "an unusually high degree of wording, often involving many words which are near synonyms and shows preoccupation with some aspects of reality" (p. 115). Consequently, by analyzing these clusters of words, classification schemes indicate the writer's ideological stance towards an issue, as pointed out by Fairclough.

Naming and predication help describe social actors and events and hence highlight the "Us" vs. "Them" dichotomy. This is because the way that people and things are named and described in texts contains ideological implications as well as reflections on relations of power and projects value judgments (Richardson, 2007). To explicate, Reisigl and Wodak (2001) emphasized the role of the referential and predicational 
strategies in positive and negative representations as well as their ideological power. They argued that the referential or nomination (naming) strategies are used to construct and represent social actors, and the predicational strategies are used to provide social actors with predications that aim at labeling them either positively or negatively. However, Reisigl and Wodak maintained that the predicational strategies "cannot neatly be separated from the nomination strategies" (p. 45) since some nominations can be considered specific forms of predications and also have certain predications associated with them. Accordingly, in the present study, both naming and predication are investigated together in almost each analyzed example under each classification scheme without giving a direct separate reference to each since both perform the same function, namely, membership categorization.

As far as naming is concerned, speakers/writers, according to Reisigl and Wodak (2001), refer to individuals or groups by including or excluding them from certain categories and thus shape the listeners'/readers' views of these individuals or groups. Fowler, Hodge, Kress, and Trew (1979) believed that different ways of naming indicate different attitudes, approaches, and intimacy relationships of the speaker/writer to the one/ones spoken to or written about. In this respect, naming identifies the ingroups and outgroups. As for predication, Reisigl and Wodak stated that "predication is the very basic process and result of linguistically assigning qualities to persons, animals, objects, events, actions, and social phenomena" (p. 54). Reisigl and Wodak identified specific forms of reference through which predications are realized based on explicit denotation as well as on more or less implicit connotation. These specific forms include, for example, attributes (in the form of adjectives, appositions, prepositional phrases, relative clauses, conjunctional clauses, infinitive clauses, participial clauses), predicates or predicative nouns, adjectives, and pronouns. They also include collocations, presuppositions, as well as both flag words (e.g. freedom, democracy) and stigma words (e.g. racism) which represent implicit predication since both connotatively convey a positive or negative deontic-evaluative meaning. In this way, providing different descriptions 
of different social actors, either negatively or positively, gives insights into group affiliations (Richardson, 2007).

\section{Literature Review}

A number of studies examining the representation of Egyptian January 25 protests in the press discourse using CDA tenets and tools were carried out, such as the two studies reviewed below because of their use of lexical analysis and investigation of international press, as is the case in the present study. To the researcher's knowledge, all the studies on the representation of Morsi's presidential era in the press discourse using CDA tackled only the portrayal of either Morsi, the Muslim Brotherhood (MB), and/or the political forces and actors whether liberals, seculars, and Islamists during his rule up to but not including the June 30 anti-regime protests and Morsi's downfall. None of these studies investigated the depiction of all or some of the main social actors involved in the antiMorsi protests during two key events discussed in the present study, namely, Morsi's constitutional declaration and the approval of the draft constitution via lexical analysis in the international press. Comparing and contrasting the portrayal of both anti-regime protests in the American and British press discourse have not been examined. Besides, investigating the classification schemes prevalent in the representation of both protests via analyzing naming and predication in order to reveal the ideological perspectives and power relations underlying such representation has not been tackled by previous relevant studies. Thus, the present study attempts to fill in these gaps.

As far as the Egyptian January 25 protests are concerned, Youssef's (2012) study used Fairclough's CDA model and van Dijk's ideological square in its investigation of the ideological differences of Egyptian (state-owned and independent) and Western (American and British) press discourses in their representation of the protests. The study also examined lexicalization suggesting bias particularly naming among other textual features. Youssef's (2012) study aimed at exploring the news media frames employed in the news reports and editorials of American (The Washington Post), British (The Telegraph), and Egyptian (Al-Ahram and 
Al-Masry Al-Youm) newspapers to represent the protests in light of the protest paradigm which trivializes and demonizes the social movements and their beliefs. It also aimed at exploring how these newspapers identified the characteristics of war and peace journalism and depicted the protesters. The study demonstrated that the Western newspapers shifted away from the protest paradigm and employed peace-reporting, taking the side of the protesters via depicting them positively.

Guzman (2016) used Fairclough's CDA model to investigate the evolvement of American news frames of the participants in the January 25 protests from its eruption to the downfall of the regime. The study examined news reports from two American news networks and investigated the way the involved social actors were named and described along with their actions. The study aimed to provide insight into the media atmosphere in which the U.S. administration shaped its response to such act. The study revealed that both news networks' frames of particular groups varied during the protests and between both news networks. The study also pointed out that such frames chiefly reflected the U.S. political ideology that favored people looking for democracy over dictatorial regimes and kept on being suspicious of Islam as represented by the MB. The employed frames created an image of the protesters as being rational and representing the US' allies, of Mubarak as being an irrational and autocratic leader and as a former friend of the US, and of the MB as an irrational group whether being an actual or potential enemy of the US, i.e. the Oriental Other despite participating in the democratic movement.

Comparing and contrasting the main findings of the above studies to those of the present study with regard to the January 25 protests are presented in Section 8.

\section{Data of the Study}

The New York Times (American) and The Guardian (British) represent prominent mainstream widely circulated news outlets. That is, they are powerful in setting the tone for reporting in their countries, which may indicate their impact on the readers who consider them sources to derive news from. In fact, premier newspapers, according to 
Lawrence (2000), provide indications to other news organizations about what is newsworthy; thus, their importance is not only related to their own wide readership but also to their influence on the content of other news media.

An equally important reason for the selection of both Western newspapers is their ownership/political affiliation which allows analyzing news reporting materials on both investigated protests from different ideological perspectives. To explicate, The New York Times' public editor Daniel Okrent (2004), a Democrat, stated that the newspaper has a general liberal bias in political coverage and news coverage of social issues. Such bias emanates from a belief in liberalism which supports the expansion of civil and political rights and liberties (Adams, 2001). The newspaper, moreover, heavily favors Democrats (Ansolabehere, Lessem, \& Snyder, 2004); accordingly, it endorsed Democrat President Obama in his presidential campaign in 2012 (Brennan, 2012). The newspaper is also an example of the elite media outlets, i.e. agenda setting media; these elite media style the content of the mainstream media in ways that meet the interests of the few elite in control of major profitable corporations (Chomsky, 1997).

The Guardian, according to its owner Scott Trust, is secured as an independent newspaper without party affiliation (Bell, 1991; Klaehn, 2010) different from The New York Times that is known for endorsing Democrats. The Guardian also has a reputation of being a platform for liberal opinions, similar to The New York Times, as well as for left-wing opinions on the political spectrum (Bell, 1991; Klaehn, 2010). However, according to Daphna Baram's book Disenchantment: The Guardian and Israel, the newspaper is underpinned as a strong supporter of the State of Israel, ignoring the civil rights and liberties of the Palestinian people, which goes against its liberal-bound attitude (Zaher, 2009).

The data collected in the present study comprises 32 news reports collected from the online archives of the examined newspapers and divided equally into 16 reports from each newspaper. Eight news reports 
from each newspaper on each protest are thoroughly examined by including the headlines, lead paragraphs, satellite paragraphs, and wrapups in the analysis (see Appendices A \& B for a detailed description of the examined news reports). Such reports cover both protests from the eruption of each until the downfall of both regimes (more specifically, from Jan. 25 to Feb. 11, 2011; and from Nov. 22, 2012, when Morsi's constitutional declaration was issued and led to the eruption of the first mass protests against his regime, to July 3, 2013). Such duration is enough to make it clear whether the newspapers stances were constant or changed during each protest and/or immediately after the end of the targeted regime in association with the then dominant power relations.

The 16 selected news reports on each anti-regime protest cover five events representing the frequently reported key events during each protest and the main phases in the escalation of each protest. The selection of these key events have been conducted based on scrutinizing upon the surface of the news reports published on both anti-regime protests in each newspaper via going through the headlines, subheadlines if available, and lead paragraphs in order to find out the most frequent reported topics, which has come up with the bulleted key events below. Furthermore, the selected events that occupied more space in each newspaper than the selected corresponding others, i.e. covered in more than three news reports have been devoted two news reports for analysis. Each two news reports issued with the same date on a given key event are ordered alphabetically as (a) and (b) based on the alphabetical order of their headlines to avoid confusion.

The five crucial selected events during the January 25 protests consist in (see Appendix A):

- The eruption of the protests on Jan. 25.

- The Friday of Anger on Jan. 28 which witnessed violent clashes between the state police and the protesters, and hence Mubarak's ordering of a nationwide curfew to save Egypt's stability.

- The Battle of the Camel on Feb. 2 that occurred in Tahrir Square between the pro- and anti-Mubarak protesters after his speech on Feb. 1 when he promised political reforms but refused to relinquish power. 
- The largest million-man protest insisting on Mubarak's departure on Feb. 8 (Day of Egypt's Love).

- Mubarak's resignation and ceding powers to the Supreme Council of the Armed Forces (SCAF) on Feb. 11.

The five central events selected during the June 30 protests lie in (see Appendix B):

- Morsi's constitutional declaration on Nov. 22, 2012, by which he was criticized for usurping all state powers and thus led to the eruption of the first mass protests against his regime on Nov. 23.

- The beginning of the rush approval of Egypt's post-January 25 protests controversial draft constitution on Nov. 29, 2012 despite the liberal and secular members' boycotting of the constituent assembly and the continuous anti-declaration and anti-draft constitution mega protests, resulting in many casualties in the first most violent clashes between the anti- and pro-Morsi protesters on Dec. 5.

- The eruption of Tamarrod's planned June 30 million-man protests calling for Morsi's downfall and early presidential elections.

- The military's statement on July 1 giving a 48-hour time limit for all parties to reach a consensus in an attempt to resolve the internal conflict and meet the people's legitimate demands.

- The military's announcement of a roadmap on July 3 by which Morsi was ousted, the constitution suspended, and a non-military interim leader appointed.

\section{Analysis and Discussion}

It can be highlighted that examining classification schemes through the analysis of choices of both naming and predication which indicate each examined newspaper's preoccupation with a specific stance helps uncover the ideologies embedded in the given news stories. In the presentation of both Egyptian protests, there is a set of biased classification schemes evident in the examined news reports that create the concept of "Us" versus "Them" according to each newspaper's ideological perspective, as seen in the below three-stage analysis representing Fairclough's (1995a) CDA framework: 


\subsection{Description Stage}

\subsubsection{Egyptian January 25 Protests}

In the news reports on the January 25 protests, the following two classification schemes are noted:

\subsubsection{Praising Protesters as Pro-Democratic}

From the very beginning of reporting on the January 25 protests, The New York Times legitimizes the protests against Mubarak and sheds light on its contextual background, as manifested in:

(1) In the days leading up to the protests, more than 90,000 people signed up on a Facebook page for the "Day of Revolution," organized by opposition and pro-democracy groups to be held on Police Day, a national holiday. The organizers framed the protest as a stand against torture, poverty, corruption and unemployment $(25-1-2011)$.

In example (1), the newspaper's support for the protests appears clearly in their reference to the first day of the protests as the Day of Revolution despite being called by the organizers themselves on the event Facebook page as the Day of Anger coinciding with the Police National Day (Aljazeera, 2011). Actually, the word revolution refers to the protests in the newspaper's selected reports from the very onset of the protests to the ouster of the president. It describes the protests as an act against the regime particularly, aiming at changing it from the very first moment. However, the word refers to the protests in a positive light since it is not associated with violence on the protesters' part as opposed to its definition in the online Oxford Learner's Dictionaries where it is defined as "an attempt, by a large number of people, to change the government of a country, especially by violent action". The newspaper also makes reference to the protests organizers as the regime's opposition and prodemocracy groups, which negatively displays the regime as being antidemocracy. Moreover, the news outlet highlights the reasons behind the anti-Mubarak protests by underpinning the protesters' view of such protests as a stand against torture, poverty, corruption, and unemployment. Such problems legitimize the protests and increase the readers' negative attitude towards Mubarak's corrupt regime. 
The New York Times explicitly assigns positive attributes to the anti-Mubarak protesters by depicting them as brave young men unsupportive of a particular political force's agenda, as evident in:

(2) Many regional experts were still predicting that the wily Mr. Mubarak, who has outmaneuvered domestic political rivals and Egypt's Islamic movement, the Muslim Brotherhood, for decades, would find a way to suppress dissent and restore control. But the apparently spontaneous, nonideological and youthful protesters also posed a new kind of challenge to a state security system $[\ldots](28-1-2011 b)$.

Example (2) shows that the protesters were spontaneous, nonideological, and youthful. That is, they were devoid of any political interests in the face of Mubarak described as being wily, for he succeeded for years to suppress his political opponents. Thus, he was also expected by regional experts to work on dispersing the protests. Moreover, the protesters' powerfulness lay in their above three attributes, for this made them represent a new kind of challenge to Mubarak's security system. Such system was not used to fighting such youthful protesters different from the regime's usual political enemies and organized movements like the MB, which implies that the protesters might be able to defeat Mubarak's regime, accordingly.

The New York Times' propensity towards the anti-government protesters continues to increase as the events unfold during the 18-day protests. It stresses the protesters' patriotism, peacefulness, and defiance to the violence of Mubarak's men and allies, as displayed in:

(3) Tens of thousands of protesters who have reimagined the very notion of citizenship in a tumultuous week of defiance proclaimed with sticks, home-made bombs and a shower of rocks that they would not surrender their revolution to the full brunt of an authoritarian government that answered their calls for change with violence $(2-$ $2-2011 b)$.

Example (3) describes the protesters as those who have reimagined the very notion of citizenship against an authoritarian government that answered their calls for change with violence in an explicit reference to the attacks of Mubarak's allies on the protesters in Tahrir Square after his televised speech on Feb. 1. In his address, the president promised reforms 
to the constitution and economy in addition to not running for re-election due in September, 2011 but refused to step down from office, the central demand of the protesters. This enraged them and made them insist on remaining in their sit-ins until Mubarak's departure. Here, the newspaper justifies the protesters' violent use of some tools to defend themselves and their revolution against the brutality of forces, known as baltageya (thugs) and paid by Mubarak's ruling party to suppress the protests and restore control, as stated in the newspaper's examined report (a) dated Feb. 2 (see also example (18)). It also confirms that this was not the only act of violence the protesters were exposed to; rather, their protests were met with cruelty at the hands of the regime throughout its first week described as a tumultuous week of defiance, which stresses the protesters' persistence and powerfulness.

Similar to The New York Times, The Guardian credits the antiMubarak protests from the very beginning by depicting them as being against Mubarak's corrupt regime and brutal police apparatus, as observed in:

(4) The protests against decades of poverty, oppression and police torture had been declared illegal by the authorities and were met with a fierce response $(26-1-2011)$.

It can be noted in (4) that the anti-Mubarak protests, sketched by the newspaper as being against decades of poverty, oppression, and police torture, were considered illegal by the government. Thus, they were faced with a fierce response in reference to the police's brutality against the protesters. This example gives a contextual background of the protests by placing emphasis on some of the reasons behind them, which legitimizes such protests and the protesters' actions. The Guardian, in the same examined report, links between the youth's protests and the forged parliamentary elections in November, 2010 when Mubarak's NDP won the majority of the seats, which demonstrates that this could be a plausible reason behind the anti-Mubarak protests.

The Guardian, like The New York Times, shows that the protests were peaceful in the face of the violence exercised by the regime, and what made 
their peaceful protests turn violent at times was the brutality of Mubarak's police forces, as seen in:

(5) Events accelerated after Friday prayers, with disciplined crowds moving from mosques shouting and raising their hands in an outburst of anger and energy in response to leaflets advising on tactics, slogans, and targets $(28-1-2011 a)$.

(6) Doused in teargas, peppered with rubbber bullets, hosed down by water cannon and beaten, they held their ground through the long day as what had been called as a peaceful demonstration quickly turned violent, with volleys of baton rounds met with petrol bombs and bricks (28 - 1 2011b).

Examples (5) and (6) display that the protesters were disciplined crowds cheering in anger and energy, not violence, and they had been conducting a peaceful demonstration. Nonetheless, they were confronted by Mubarak's fearsome police forces who caused the protesters to be doused in teargas, peppered with rubber bullets, hosed down by water cannon, and beaten. The protesters, in turn, responded violently in defense of themselves by throwing bricks and petrol bombs on the police forces.

Mubarak's cruel and unfair treatment of the protesters was embodied in The Guardian via not only his police's physical violence but also his shocking concessions in the sense that they were too late to be of benefit to the protesters, as noted in:

(7) Stunned protesters listened to Mubarak in disbelief. In the hours before his speech, thousands of pro-democracy activists had poured in to Tahrir Square for an impromptu victory party in expectation that the president was about to quit [...] (11-2-2011a).

As noted in (7), the protesters are described as stunned and in disbelief on hearing Mubarak's decision on Feb. 10 that he would hand over some powers to his Vice President Suleiman but would not resign. This tremendously shocked thousands of pro-democracy activists who expected him to leave office and were ready to celebrate. The word victory used in reference to the state of the protesters in anticipation of 
Mubarak's quit reflects the animosity that existed between the former and Mubarak's authoritarian regime which had once victimized them.

To sum up, all the aforementioned examples indicate that the Western newspapers at issue supported the anti-Mubarak protesters throughout the 18-day protests.

\subsubsection{Reproaching Mubarak's Autocratic Regime and Fierce Counter-Protests}

The New York Times presents Mubarak and his regime negatively by underpinning his autocracy, his government's corruption, his police's brutal attempts to suppress the protests, and his supporters' vicious counter-protests. To start with, the newspaper sheds light on the president's flaws as a ruler, as seen in:

(8) Since Jan. 14, when President Zine el-Abidine Ben Ali of Tunisia fled his country during a popular revolt, autocrats throughout the region have fretted about responses by their own restive populations who shared many of the grievances that toppled Mr. Ben Ali: rampant corruption, injustice, high unemployment and the simple lack of dignity $(25-1-$ 2011).

In (8), the newspaper makes an analogy between Mubarak and all the rulers across the Middle East region, like the toppled Zine el-Abidine Ben Ali of Tunisia. They are all referred to as autocrats, and their people are pictured as restive populations who suffered from widespread corruption, injustice, unemployment, and lack of dignity. Such grievances, as named by the newspaper, had led to President Ben Ali's ouster, and hence they were likely to cause the same results as to Mubarak's case since the Egyptian people under Mubarak's presidency shared the same misfortunes of the Tunisians.

Mubarak also used violence, as presented in The New York Times' coverage, to oppress the protests via his infamously efficient police and aggressive allies, as evident in:

(9) The protesters came from every social class and included even wealthy Egyptians, who are often dismissed as apolitical, or too comfortable to mobilize. For some of them in the crowd on Friday, the brutality of the security forces was a revelation. "Dogs!" they yelled at 
the riot police, as they saw bloodied protesters dragged away (28 - 1 2011a).

(10) President Hosni Mubarak struck back at his opponents on Wednesday, unleashing waves of his supporters armed with clubs, rocks, knives and firebombs in a concerted assault on thousands of antigovernment protesters in Tahrir Square calling for an end to his authoritarian rule $(2-2-2011 a)$.

In (9), the brutality of Mubarak's police forces is painted as a revelation as seen by some of the wealthy Egyptian protesters. They called the riot police $\operatorname{dog}_{s}$ due to the bloodied protesters who fell during the police's fierce attacks on them on Feb. 28. The word $\operatorname{dog}(s)$ in Arabic signifies a negative connotation whether in standard Arabic or Egyptian Arabic. It connotes نجاسة 'uncleanliness' in the former (Abdul-Raof, 2001), and it is considered an insult and a common swear word in the latter uttered to degrade someone as being filthy, dishonest, or immoral (Arabic Learning Resources, 2007). The newspaper uses the word $\operatorname{dog}_{s}$ as a translation of the Arabic word كلاب since it could mean in English "a worthless or contemptible person", as stated in Merriam-Webster online dictionary.

Example (10) underscores that the assaults of the president's supporters on the protesters in Tahrir Square on Feb. 2 were directly associated with Mubarak, as noted in the example, as well as his ruling National Democratic Party (NDP), as stated in the same examined report (a) dated Feb. 2. This is highlighted through portraying the attacks as a concerted assault in the lead paragraph in (10) and describing the supporters as being armed with clubs, rocks, knives, and firebombs. Mubarak's prior knowledge of and responsibility for such cruel attacks is further asserted in the example via assigning both the verb phrase unleashing waves of his supporters to Mubarak and the negative attribute authoritarian to his rule, which credits the protests and their demand of the downfall of his regime. 
Parallel to The New York Times, The Guardian depicts Mubarak as a tyrannical and obsessed-with-rule president, as in:

(11) Amid all the confusion, the first cracks in the 30-year-old dictatorship began to appear $(28-1-2011 b)$.

In consonance with the American newspaper, the British newspaper underpins in example (11) that Mubarak was a long-time despotic ruler. This is clear in delineating his regime as the 30-year-old dictatorship.

In The Guardian, Mubarak's totalitarianism, similar to The New York Times, is embodied most in the atrocious acts of his police forces as well as the barbarous attacks of his allies on the anti- regime protesters, as obvious in:

(12) When Mohamed ElBaradei arrived in Midan Giza, a traffic-snarled interchange on the west bank of the Nile, for Friday prayers, he saw a graphic illustration of Egypt under President Hosni Mubarak: neat rows of police and plainclothes security officers lining the streets to maintain calm.

By the time he left the central Cairo square an hour or so later it was in flames, doused with teargas and water cannon and with rocks flying through the air - a glimpse of what an Egypt sick of Mubarak had become $(28-1-2011 b)$.

(13) By late last night, contact with those trapped in the square was limited to desperate tweets as most journalists were driven out. They spoke chillingly of the army withdrawing from the side streets around the square and gangs of pro-Mubarak thugs advancing towards them armed with knives and swords $(2-2-2011 b)$.

Example (12) sheds light on the violence committed by the police against the protesters to break up their protests via describing the central Cairo square as in flames and doused with teargas and water cannon and with rocks flying through the air. Such a scene is negatively characterized as a glimpse of an Egypt sick of Mubarak. According to ElBaradei, what represented a graphic illustration of Egypt ruled by Mubarak was neat rows of police and plainclothes security officers lining the streets to maintain clam. All these images display Egypt as a police state ruled by a villain. 
This cruelty is significantly pointed out in example (13) which paints the pro-Mubarak protesters, like the American newspaper, as gangs of pro-Mubarak thugs armed with knives and swords. In contrast, the anti-Mubarak protesters are described as trapped in the square and their only means of communication as desperate tweets. This kind of comparison between both parties projects the anti-Mubarak protesters as victims and his allies as victimizers. Like the American newspaper, the British newspaper asserts that the brutish attacks of Mubarak's supporters on the protesters in Tahrir Square were plotted by his men to quell the protests, as displayed in the newspaper's examined report (a) dated Feb. 2. It states that some of Mubarak's supporters were plainclothes police hidden in ranks. This arouses the readers' sympathy with and support for the protesters, on the one hand, and their contempt for both Mubarak and his backers, on the other, because of the latter's connived unfair fights against the anti-Mubarak unarmed protesters.

To conclude, all the quoted examples in this section evince that the Western newspapers at hand were against Mubarak and his regime throughout the 18-day protests.

(i) 7.1.2 Egyptian June 30 Protests

As far as the analyzed news reports on the June 30 protests are concerned, the following two biased classifications schemes can be underscored:

\subsubsection{Denigrating Anti-Morsi Protesters as a Hurdle to Democracy}

Different from The New York Times' positive representation of the anti-Mubarak protesters, it provides negative portrayal of the anti-Morsi protesters from the very beginning of the protests against Morsi, i.e. on Nov. 23, 2012. Such portrayal continues to be negative on June 30, 2013 onward by emphasizing their violent acts despite admitting their massive, popular protests against the regime. As for the newspaper's pre-June 30 coverage of the anti-regime protests, it attempts to negatively paint such protests as a consequence of a mere conflict over power initiated by the regime's basically disunited minor opposition, as exposed in the examples below:

(14) The battles that raged on Friday - over power, legitimacy and the mantle of the revolution - posed a sharp challenge not only to $\mathrm{Mr}$. 
Morsi but also to his opponents, members of secular, leftist and liberal groups whose crippling divisions have stifled their agenda and left them unable to confront the more popular Islamist movement led by the Muslim Brotherhood (23 - 11 - 2012).

(15) Even after two years of periodic battles between protesters and police, Egyptians said they were shocked and alarmed by the spectacle of fellow citizens drawing blood over matters of ideology or political power $(5-12-2012)$.

The newspaper, as displayed in (14), pictures the protests in this phase of its coverage as the result of a conflict between two political factions: members of secular, leftist and liberal groups of opposition and the Islamist movement led by the $\mathrm{MB}$, apart from ordinary Egyptian citizens. The violent clashes between the two parties because of Morsi's constitutional declaration which granted him broad powers over court law are depicted as battles representing a sharp challenge to both Morsi and his opponents in (14) and as drawing blood over matters of ideology or political power in (15). However, Morsi's opponents are blamed for the onus of the political crisis. This is because their crippling divisions, as shown in (14), hindered them from carrying out their agendas. Such divisions, hence, made them unable to confront the MB positively painted as the leader of the more popular Islamist movement. That is, Morsi's opponents represented a restricted category of the people, which, in turn, lessens the influence and significance of the protests against Morsi's policies and decisions. This shows that The New York Times is not in favor of the anti-regime protesters. The charter meant here is Egypt's post-January 25 protests draft constitution which was protested against by almost a quarter of the constituent assembly members representing Christians, liberals, and leftists. They believed, as stated in the newspaper's analyzed reports on the pre-June 30 protests, that the Islamists wanted quick approval of the draft constitution in order to impose their will and vision over the rest of the Egyptians.

The American newspaper's tone towards the anti-Morsi protesters in its coverage of the June 30-July 3 protests incorporates a fake positive layer manifested in admitting that they were not only members belonging to secular, leftist, and liberal groups but also ordinary citizens. However, 
it adversely foregrounds them as perpetrators of violence against Morsi's backers. This delegitimizes their demands for democracy, justice, and freedom that were supposed to be achieved by the departure of Morsi accused by them of turning into an autocrat similar to former President Mubarak. View the following example:

(16) By Monday morning, however, clashes between Brotherhood supporters and opponents had left $\mathbf{1 5}$ dead across the country. [...] And in Cairo a mob attacked the Brotherhood's headquarters with Molotov cocktails, setting it on fire, breaking down its doors and looting the building.

A few Brotherhood members trapped inside the darkened building tried to hold off the attackers by firing blasts of birdshot, and after midnight other gunmen evidently arrived as well. [...] $(1-7$ - 2013).

The clashes between the MB's rivals and allies portrayed as opponents and supporters, as observed in (16), led to victims on both sides across Egypt as seen in referring to them in number as 15 deaths. Nonetheless, the anti-Morsi protesters are the ones pictured as initiators of violence. The protesters who vigorously demonstrated in front of the MB's headquarters in Cairo are negatively marked out as attackers and a $m o b$ assaulting the MB's office, putting it on fire, and looting the building. The word mob in the Longman Dictionary of Contemporary English Online means "a large noisy crowd especially one that is angry and violent". Such word is adopted instead of using a neutral expression like a "group of people" or "some protesters". On the contrary, when the anti-Mubarak protesters set fire to the NDP's building during the January 25 protests, i.e. a similar incident to the one described above, the newspaper called them Egyptians and pro-democracy protesters since it presented the NDP as a representative of Mubarak's despotic rule (Fahim, Slackman, \& Rohde, 2011). The impact of such adverse depiction of the anti-Morsi protesters increases through the presentation of the attacked, i.e. the Brotherhood members as helpless by showing them as trapped inside the darkened building, and hence they had no way out but defending themselves by firing blasts of birdshot. What made it worse was that by midnight the attackers were joined by other gunmen, which 
raises the readers' sympathy with Morsi's endorsers and wrath against his armed opponents. The example reveals that the newspaper is not in support of the anti-Morsi protesters; this is evident in its bid to deform their protests through shaping them as being a mere embodiment of either the conflict of ideology and power or unjustified aggression.

On July 3, The New York Times explicitly calls the military's ouster of Morsi, which resulted from the public protests against his regime, a coup in its authorial voice. Examine the following example:

(17) The generals built their case for intervention in a carefully orchestrated series of maneuvers, calling their actions an effort at a "national reconciliation" and refusing to call their takeover a coup. [...] $(3-7-2013 a)$.

In (17), the army's intervention in the anti-Morsi protests is overtly pictured by the newspaper as carefully orchestrated series of maneuvers that resulted in a coup. That is, such intervention was plotted though, as reported by the newspaper in the military's voice, it was positively marked out as an effort at a 'national reconciliation'. This indicates the newspaper's attempt to distance itself from such description through the use of strategic quotation to highlight its disapproval (van Ginneken, 2002).

Akin to The New York Times, The Guardian yields a negative presentation of the anti-Morsi protesters contrary to its positive depiction of the anti-Mubarak protesters. In The Guardian's pre-June 30 coverage of the anti-regime protests, it concenters on underscoring the unrepresentativeness of the anti-Morsi protesters and their unfair view of Mori as a new dictator due to his constitutional declaration. See the following examples:

(18) The protests against the decree appear - for now at least - to have united the fissiparous and largely secular opposition to the Muslim Brotherhood (23 - 11 - 2012).

(19) Morsi's aides said the presidential decree was to speed up a protracted democratic transition that has been hindered by legal obstacles. Morsi's rivals, however, were quick to condemn him as a new autocratic pharaoh who wanted to impose his Islamist vision on Egypt (23-11-2012). 
In example (18), the anti-MB protesters are described as being basically fissiparous but got united owing to their objection to Morsi's extra-legal presidential decree and largely secular similar to the American newspaper. The Guardian, in (19), blames Morsi's opponents for being quick to condemn Morsi as a new autocrat pharaoh. It points out in the indirectly reported words of Morsi's aides, where the voice of the reporter cannot be distinguished from the quoted source's voice (Fairclough, 1995b), that the presidential decree was meant to end as soon as possible the protracted democratic transition delayed due to legal obstacles. This reflects the newspaper's attempt to underpin a justification for Morsi's declaration, which, in turn, lessens some of the president's responsibility for Egypt's severe division into two rival factions. It also puts the onus of such political crisis on both the anti-Morsi protesters' rush to negatively judge his intention towards and vision of Egypt as a democracy and Mubarak-era judiciary institution putting obstacles on the president's way to democracy, as stated in the examined report dated Nov. 23 and seen in (19).

From June 30 ahead, The Guardian, similar to The New York Times, centers on explicitly derogating the anti-Morsi protesters and discrediting their actions despite confessing their huge number. This is seen in defining the protesters in relation to ex-authoritarian President Mubarak, as in:

(20) Those calling for the end of his presidency include an uneasy alliance of disaffected backers, as well as supporters of the former regime - many of whom were on opposite sides of a violent divide in the heady months after Mubarak fell (3-7 - 2013a).

In example (20), the newspaper, in its authorial voice, underpins that the anti-Morsi protesters formed an uneasy alliance, i.e. an unstable alliance, for it included both disaffected backers and supporters of the former regime. Both were actually in a violent divide since Mubarak's downfall. Such delineation, consequently, stirs the readers' doubt about the anti-Morsi protesters' real intent behind the protests. 
The Guardian asserts that the military's ouster of Morsi in response to the public's demand is nothing but a coup, as evincible in:

(21) It took the gathering until dark to reveal a clear reality; the military coup against President Mohamed Morsi, foreshadowed all week, had crept up on everybody. Egypt's first democratically elected president had lost his fight to keep any semblance of the office he has held for $\mathbf{1 2}$ fraught months.

In the subheadline in example (21), the newspaper describes the military coup against Morsi as a clear reality. This negative representation of the military's intervention is contrasted with the positive depiction of Morsi as Egypt's first democratically elected president. Describing his term in office as 12 fraught months further incites the readers' sympathy for Morsi and animosity towards both the army who exploited its power to remove Morsi and the Egyptian protesters who welcomed the army's action against the legitimate presidency. This demonstrates that the British newspaper, like the American newspaper, is in favor of Morsi's regime.

In fact, all the analyzed examples in this section unveil that both Western newspapers demonized the protesters as being obstacles on Egypt's way to democracy.

\subsubsection{Provoking Sympathy for Morsi and His Islamist Allies}

In contrast to The New York Times' representation of the brutality of Muabarak, his police state, and supportive protests, the newspaper emphasizes Morsi's positive political activities, and no violent action on his backers' part is attributed to him. The newspaper, in its investigated reporting on the pre-June 30 protests, differentiates between Morsi, on the one hand, and his Islamist backers in authority, i.e. the MB, on the other. It draws the former in a more favorable light, along with his Islamist supporters in the public from the very beginning of the anti-Morsi protests which started on Nov. 23, whereas the latter are purportedly blamed for provoking the opposition's animosity against the regime (see example (23)). To expound, The New York Times underpins the positive and negative aspects of Morsi's constitutional declaration. However, it positively provides justifications for his declaration in the form of a detailed political background. Think over the example below: 
(22) With a constitutional assembly on the brink of collapse and protesters battling the police in the streets over the slow pace of change, President Mohamed Morsi issued a decree on Thursday granting himself broad powers above any court as the guardian of Egypt's revolution, and used his new authority to order the retrial of Hosni Mubarak. Mr. Morsi, an Islamist and Egypt's first elected president, portrayed his decree as an attempt to fulfill popular demands for justice and protect the transition to a constitutional democracy. But the unexpected breadth of the powers he seized raised immediate fears that he might become a new strongman. [...] $(22-11-2012)$.

In the lead paragraph in (22), Morsi is pictured as an Islamist meaning in Merriam-Webster online dictionary someone belonging to "a popular reform movement advocating the reordering of government and society in accordance with laws prescribed by Islam", which may have negative connotations from the perspective of some people. However, such term is no longer used as a synonym for Islamic fighters, militants, extremists, or radicals, which results in fewer negative generalizations in the coverage of issues related to Islam and Muslims (Slate, 2013). Hence, such a term does not contrast with the positive representation of Morsi, in the same example, as being Egypt's first elected president, which gives a sense of legitimacy to him as a leader of the country and to his regime. His presidential decree is depicted negatively as granting him broad power above any court and unexpected breadth of the powers, which raised his opponents' immediate fears from him becoming a new strongman similar to his predecessor Mubarak. However, it is also painted positively as allowing him to be the guardian of Egypt's revolution. Besides, in order to gain the readers' support for Morsi's decree, the reasons behind issuing it are provided in the lead paragraph of the report. It describes the constitutional assembly as being on the brink of collapse. It also highlights the clashes between the protesters and police due to the slow pace of change and underscores the fact that the decree would enable Morsi to order the retrial of Mubarak and all his officials accused of killing and badly injuring anti-Mubarak protesters. 
The newspaper, moreover, favorably presents Morsi's own view of his decree as an attempt to fulfill popular demands for justice and protect the transition to a constitutional democracy.

Moreover, both positive and negative aspects of the draft constitution are underscored by The New York Times; nonetheless, the former are specified and detailed in an attempt to argumentatively support the president's decrees. Though the MB is blamed for the onus of the political conflict over Morsi's power grab, the newspaper tries to soften such burden via highlighting the noble motives behind their political activities, as noted in:

(23) Racing against the threat of dissolution by judges appointed by ousted President Hosni Mubarak, and ignoring howls of protest from secular opponents, the Islamists drafting Egypt's new constitution voted Friday to approve a charter that human rights groups and international experts said was full of holes and ambiguities.

The result would fulfill some of the central demands of the revolution: the end of Egypt's all-powerful presidency, a stronger parliament and provisions against torture or detention without trial [...] and would reject the demands of ultraconservative Salafis to impose puritanical moral codes $(29-11-2012)$.

Since Morsi was accused by the protesters that his decrees were issued for the good of his MB, and accordingly they viewed him as not a president for all Egyptians but only a representative of the MB in power (Bubalo, 2012; Sharp, 2013), the newspaper attempts to prove such a conviction is false. In (23), the positive points in the draft charter are pictured as representing the central demands of the revolution and are numerated as the end of Egypt's all powerful presidency, a stronger parliament and provisions against torture or detention without trial, as well as the rejection of the demands of ultraconservative Salafis to impose puritanical moral codes. In contrast, the negative points in the draft are collectively and abstractly named as holes and ambiguities in the first part of the example which represents the lead paragraph. This 
indicates that the newspaper does not adopt the negative perspective of the secular opponents towards the content of the charter. Such mixed representation is also evincible in portraying the conflict situation in which the Islamist members of the assembly approved the charter, as embodied in the following two attributes in the form of participial groups: racing against the threat of dissolution by judges appointed by ousted President Hosni Mubarak and ignoring howls of protest from secular opponents. To explain, the newspaper starts the lead paragraph with a justification for the Islamists' attempt to quickly approve the draft charter; it is the fact that the Supreme Constitutional Court was expected to issue a ruling that could dissolve the assembly as also pinpointed in the wrapup of the investigated report dated Nov. 29. Moreover, associating the judges with Mubarak rouses the readers' doubt about their intent towards the MB whom they might want to bring down in revenge for their ousted president. The newspaper's sympathy with the MB is made more evident in the example through contrasting them with the ultraconservative Islamists, as seen in the former's rejection for letting the latter enforce their extremely rigid moral rules in the draft constitution claimed to be Islamist-slanted by the anti-declaration and draft constitution protests. This lessens the negative effect of the Islamists' ignoring such protests and somehow demonstrates the newspaper's endorsement of their action.

Throughout The New York Times' coverage of the anti-Morsi protests, Morsi's public Islamist backers are portrayed as the defenders of the legitimate presidency, not attackers. Accordingly, their aggressive acts against the anti-Morsi protesters are either justified or alleviated. Moreover, the newspaper negates any prior intended violence on the part of the MB against the anti-regime protesters. Note the following example: (24) Earlier, speaking to a crowd of Islamists armed with makeshift clubs and hard hats at a rally in Cairo, a senior Brotherhood leader, Mohamed Beltagy, called on the crowd to defend Mr. Morsi's "legitimacy" as the elected president. [...] $(1-7-2013)$.

As observable in (24), the Islamists rallied to defend the elected president's legitimacy, as marked out by the MB. Such crowds of 
Islamists are imaged as armed with makeshift clubs and hardhats. That is, their tools could not be used to initiate violence against millions of protesters or even to terrorize much smaller groups but could possibly be used in mere self-defense. This picture of Morsi's adherents, particularly the MB stimulates the readers' empathy for their helpless status, for they are also presented in the newspaper's analyzed reports on July 3 as involved in tensions with two fronts: civilian opponents and security forces. This reflects the American newspaper's bias towards Morsi's regime.

In resemblance to The New York Times, The Guardian, different from its negative representation of Mubarak's authoritarian regime, draws a positive image of Morsi via providing grounds for his defected presidential decrees. This is evincible in underpinning the good side of his constitutional declaration in the example below:

(25) The move was doubly surprising as Morsi, who has had the power to proclaim laws since the parliament's lower house was dissolved in June, has been extremely circumspect in the use of his authority.

The declaration comes in the midst of an increasingly acrimonious battle over the writing of Egypt's new constitution. Liberal and Christian members withdrew from the constituent assembly during the past week in protest at what they say is the hijacking of the process by Morsi's allies, who they fear are trying to push through a document that will have an Islamist slant, [...] $(22-11-2012)$.

Designating Morsi's issuing of such edict as a doubly surprising move in (25) evokes the readers' thinking about the serious reasons for Morsi's declaration, especially that his positive acts as a political leader are spotlighted in the example. He is pictured as being extremely circumspect in the use of his authority since the dissolution of the lower chamber of parliament in June, 2012. Actually, one of the reasons behind his decree is presented as the increasingly acrimonious battle over the writing of Egypt's new constitution between the liberal, secular, and Christian members of the assembly, on the one hand, and the Islamists, on the other. The former walked out of the assembly protesting the latter's 
bid to create an Islamist-slanted charter, and such an action is painted by the former as the hijacking of the process by Morsi's allies. Accordingly, the decree gave the assembly two more months to finish the work and reach a consensus, which was supposed to lessen the opposition's harsh criticism of the assembly but it did not. The decree also granted it immunity from being dissolved by legal challenges expected to be decided in December, 2012. This was because the lower house of parliament, also dominated by the Islamists, had been dissolved by a court decision owing to the illegal rules governing its election, as stated in the examined report dated Nov. 22. This, in turn, implies that the MB was somehow aimed to be defeated by their foes.

In contrast to Morsi's favorable image, his Islamist allies, in The Guardian's coverage of the pre-June 30 protests, are the ones blamed instead for adding to the mounting sense of Egypt's political predicament via highlighting the negative aspects of the Islamist-slanted constitution, as seen in:

(26) The draft constitution has been criticised for not protecting the rights of women and minority groups, and many journalists see it as restricting freedom of expression. Critics also say it empowers Islamic religious clerics by giving them a say over legislation, while some articles were seen as tailored to get rid of the Islamists' enemies $(5-12-2012)$.

Example (26) explicates in some detail why the charter was harshly disputed and criticized different from the American newspaper where the positive aspects are stated along with the negative aspects but the former are topicalized and detailed, whereas the latter are vaguely named (see example (23)). It is painted as not protecting the rights of women and minority groups, restricting freedom of expression, and tailored to get rid of the Islamists' enemies in addition to enabling Islamic men of religion to participate in the process of making laws. These reasons led the secular members of the assembly to quit it, accusing Morsi of attempting to force an Islamist-slanted constitution via his Islamist allies, which instigated anti- and pro-Morsi protests and confrontations. 
Starting on June 30 forward, Morsi's Islamist endorsers including the $\mathrm{MB}$ and those belonging to the public are depicted by The Guardian in a sympathetic light as sizable but subdued and peaceful. Even after the army's final statement where the ouster of freely elected President Morsi was announced, which stirred his supporters' fury and frustration, the latter only threatened violence but no actual action was taken on their part, as apparent in:

(27) Down in the crowd, the mood was charged. [...] Others were clad in a motley selection of hardhats, cycle helmets, homemade shields and martial arts vests - in case of attack. Some carried sticks and improvised clubs. "Seculars will never rule Egypt again," some chanted carrying white funeral clothes that gave the impression they were willing to be martyred for their cause $(3-7-2013 b)$.

Example (27) demonstrates that Morsi's backers were peaceful since they are depicted as charged but only to defend the presidential palace against the expected attacks by the anti-Mors protesters, using various domestic tools like sticks and improvised clubs. They are also pictured as clad in a motely selection of hardhats, cycle helmets, homemade shields and martial arts vests, carrying white funeral clothes, and willing to be martyred for their cause. However, such description of the things they were covered in and the tools they were using does not give the impression that they could initiate violence or instigate a civil war. It implies that they could only defend themselves against attacks by Morsi's opponents and that the former would be the only affected participants. Consequently, such image of Morsi's supporters let them gain the readers' empathy and understanding of their tangled situation, which indicates that the British newspaper is in behalf of Morsi and his allies.

To sum up, the investigated examples in this section reflect that the Western newspapers at issue had a leaning towards Morsi as Egypt's first democratically elected president and they were sympathetic with his allies.

\subsection{Interpretation Stage}

The interpretation phase helps uncover how the reporters relied on the classification schemes as a discursive tool to legitimize or delegitimize the January 25 and June 30 protests. Such biased 
classifications schemes which were created by naming and predication revealed clear group polarization dividing the involved social actors into an ingroup and an outgroup. The four classification schemes examined in Section 7.1 represent the key topics that were emphasized whether positively or negatively by the examined news outlets in their representation of each protest.

To explicate, it can be noted, in the investigated data on the January 25 protests, that The New York Times and The Guardian provided positive representation of the anti-Mubarak protesters as being prodemocracy, diverse, peaceful, brave, and defiant in face of the autocratic president, his ferocious police apparatus, and his supporters' counterprotests which mainly comprised plainclothes police and NDP's paid thugs attempting to disperse the protests. Accordingly, there was a focus on the violent clashes between Mubarak's police and allies, on the one hand, and the protesters, on the other, which negatively represented the regime. Both newspapers highlighted that it was the former who initiated violence and the latter were merely responding to their brutality in defense of themselves. This, in turn, stirred sympathy for the ingroup's victims. What made the readers identify much more with the protests is the fact that both Western newspapers somewhat contextualized the protests by being keen on emphasizing the social and political circumstances that gave rise to Egypt's protests, such as Mubarak's authoritarian regime, his unwillingness to carry out fundamental political and economic reforms, repression, backwardness, poverty, and muting the opposition. In addition, both news outlets underpinned the protesters' demand of Mubarak's departure as being the main demand on the very first day of their protests and hence positively named their protests a revolution with no instigated violence of any sort ascribed to the protesters.

In the analyzed data on the June 30 protests, on the contrary, it can be noted that the coverage of The New York Times and The Guardian was more focused on Morsi and his allies than the anti-Morsi protesters. Both newspapers demonized the anti-Morsi protesters as a hurdle to Morsi's 
endeavor to turn Egypt into a democracy and violent people. During their protests against Morsi's extra-legal presidential decree as well as Islamistslanted constitution, they were referred to collectively as mainly secular and liberal forces. They were described as a divisive minority in the face of Morsi's supportive Islamist forces in an attempt on the newspapers' part to show them as two political factions fighting over power apart from Morsi. In the June 30-July 3 protests, both parties were called Morsi's opponents and supporters since both groups represented large sectors of the Egyptian public. The protesters' demand for Morsi's departure was not also highlighted except in the coverage of the protests on June 30 although the protesters chanted slogans calling for Morsi's stepping down in their very first protests against his decrees (Sharp, 2013). Moreover, ousting Morsi through the military's intervention was depicted by both newspapers as an attempt on military's part to take over power once again, i.e. a military coup against the democratically elected head of state. This negative characterization of the army's intervention degraded the June 30 protests, discredited the protesters' demands, and reflected the newspapers' leaning towards Morsi and his advocates.

As for Morsi, he was represented positively as Egypt's first democratically elected president whose decrees, negatively evaluated by his opponents, were favorably depicted by both Western newspapers as being issued for the good of his country since he wanted to end the delayed political transition, find a way out for the deadlocked constitutional assembly, and overcome the Mubarak-era institutions' attempts to defeat the MB. In contrast, his MB was the one purportedly blamed, instead, for deepening the political crisis because of their firm grip over Egypt's political life. Both Western newspapers, moreover, mainly spotlighted the plight of the president's Islamist backers in the public. Dissimilar to Morsi's opponents, they were imaged in a sympathetic light as sizable but oppressed defenders of the legitimacy of the elected presidency against the anti-Morsi protesters' violent attacks. This was manifested, for example, in the latter's attacks on the MB's offices across Egypt and in the former's being armed with domestic tools that could only be used in self-defense, which provoked negative feelings towards the anti-Morsi protesters and empathy for Morsi's proponents. 
Such interpretation of the utilized naming and predication and their generation of the investigated biased classification schemes revealed the dichotomous model of Us vs. Them in each newspaper's coverage of both protests, as elucidated in Tables 1 and 2 below:

Table 1: The Dichotomous Model of Us vs. Them in the January 25 Protests Coverage

\begin{tabular}{|c|c|}
\hline \multicolumn{2}{|c|}{ The New York Times \& The Guardian } \\
\hline Ingroup & Outgroup \\
\hline anti-Mubarak protesters & Mubarak's regime, supporters \\
& \\
\hline
\end{tabular}

Table 2: The Dichotomous Model of Us vs. Them in the June 30 Protests Coverage

\begin{tabular}{||c|c||}
\hline \multicolumn{2}{|c|}{ The New York Times \&The Guardian } \\
\hline Pre-June 30 Protests Coverage Phase \\
\hline Ingroup & Outgroup \\
\hline Morsi, public Islamist backers & $\begin{array}{c}\text { anti-Morsi protesters } \\
\text { ostensibly MB (owing to their political } \\
\text { dominance; however, justified or } \\
\text { alleviated every now \& then in the } \\
\text { coverage) }\end{array}$ \\
\hline $\begin{array}{c}\text { June 30-July 3 Protests Coverage Phase } \\
\text { MB, public Islamist } \\
\text { backers }\end{array}$ & anti-Morsi protesters \\
\hline
\end{tabular}

The interpretation phase can be understood in much depth through an explanation of the social practices of the newspapers, i.e. the relation of news discourse to other social institutions and wider social factors, which shaped their ideological stances towards both protests. 


\subsection{Explanation Stage}

This stage of Fairclough's (1995a) model of CDA helps examine the power relations which shaped the January 25 and June 30 protests discourse. Therefore, it is drawn upon the ownership/political affiliation of both examined newspapers at issue and the notion of media as an ISA in the sense of Althusser (1971) which explain how the investigated news discourses representation of both protests was bound to the ideological stances of their news institutions in relation to the then official ideological mainstream views. Numerous scholars maintained that media mediates the ruling class' ideology through its content; that is, the media cannot be seen separately from state institutions or other elite powerful groups (Ashley \& Olson, 1998; Blommaert, 2005; Cotter, 2010; Cottle, 2000; Dunlevy, 1998; Fairclough, 1994, 2003, 2006; Fowler, 1991; Gitlin, 1980; Herman \& Chomsky, 2002; Hodge \& Kress, 1993; Iggers, 1999; Manning, 2001; McLeod, 1995; McLeod \& Hertog, 1992; McQuail, 1993; Molotch \& Lester, 1974; Murdock, 2000; Richardson, 2006, 2007; Tuchman, 1978; van Dijk, 1991, 1993a, 1996, 1998, 2000; Wayne, 2003). Thus, the media discourse can be manipulated to sustain or resist hegemony at times of crisis, for example, based on the then power balance.

To expatiate, the examined newspapers' coverage of the January 25 and June 30 protests is ideologically biased and slanted. It can be pointed out, based on the description and interpretation levels of analysis (see Sections $7.1 \&$ 7.2), that both The New York Times' and The Guardian's coverage of the January 25 protests evinces that they were prone to take the side of the protesters by depicting them positively as people fighting for the democracy other Westerns cherished and picturing Mubarak as a dictator killing his people to stay in power. This could be reflective of the fact that both newspapers are liberal-bound, as Brennan (2012) and Okrent (2004) as well as Bell (1991) and Klaehn (2010) put it, respectively; that is, they are supposed to defend democracy and civil as well as political rights. Furthermore, President Obama entirely supported the pro-democracy protests and announced his disapproval of any violence committed against them, but his stand towards Mubarak was not definite at the outbreak of the protests, as maintained by Green (2011) 
and Ross, Moore, and Swinford, (2011). In fact, Ross et al. highlighted that the White House was backing Egyptian pro-democracy activists while dealing with Mubarak in public as their closest ally in the Middle East. Despite the fact that Obama, at first, urged Mubarak to work seriously on political reforms, he eventually called for an urgent transitional government headed by Vice President Omar Suleiman after the Battle of the Camel on Feb. 2 (Holmes, 2012; Sharp, 2013). Such battle resulted in a crack between the US administration and Europe, on the one hand, and Mubarak's regime, on the other, since the former overtly asked him to stop violence against the peaceful protesters (Holmes, 2012; Sharp, 2013). That is, when Egypt's stability was endangered by the public protests against Mubarak, the US supported the army's takeover. In fact, The New York Times is an example of the mainstream media influenced by powerful institutions like governments (Ashley \& Olson, 1998; Blommaert, 2005), one of the elite media outlets affecting both decision makers and the public (Chomsky, 1997; Herman \& Chomsky, 2002), and known for its support for Democrat Obama (Ansolabehere et al., 2004; Brennan, 2012). These could be considered grounds for its favorable representation of the anti-Mubarak protests.

As to the UK government's reaction to the anti-regime protests in Egypt, like the US, Foreign Secretary William Hague and Prime Minister David Cameron also condemned the use of violence against the peaceful protesters and asked Mubarak to undertake immediate political reforms and reinforce the civil rights and the rule of law (Ross et al., 2011). Such demands were, however, more constant than the US' throughout the 18day protests, and the UK government underpinned that the protesters did have genuine criticisms similar to their counterparts in the countries across the Middle East (Foreign and Commonwealth Office, 2011). Thus, Cameron announced that Mubarak's downfall and the military's role of governing Egypt during the transitional term represented a precious moment of promoting real democracy in Egypt (Goodman, 2011). The UK's attitude may explain The Guardian's propensity towards the antiMubarak protesters. Despite being known as a platform for liberal opinions (Bell, 1991; Klaehn, 2010) and as an example of open 
journalism (Zaher, 2009) which is supposed to support pro-democracy protesters, it is also a mainstream media outlet similar to The New York Times. That is, it belongs to an ISA that somehow endorses the given government's evaluation, interpretation, and perspective of particular events (Althusser, 1971).

As far as the June 30 protests are concerned, both Western newspapers were inclined to side against the anti-Morsi protesters in favor of the Islamist president to the extent that they called the Egyptian military's intervention to satisfy the people's will a coup. This goes against the two newspapers' liberal perspective concerning supporting people's civil rights. That is, both news outlets should have supported the anti-Morsi protesters considering Morsi a new autocrat, similar to Mubarak, who did not really work on promoting democracy and providing fundamental reforms of any kind. The stances of the two newspapers, being mainstream media outlets as explained above, might be more or less indicative of the American and British mainstream views. To illustrate, Ibrahim (2013) stated that the Obama administration, via the U.S. Ambassador to Egypt Anne Patterson, announced its support for the Egyptian government and refusal of turning Egypt into a military state. Moreover, Obama repeatedly asked the opposition in general and the Copts in particular not to protest against Morsi being a democratically elected president dissimilar to Mubarak but to have dialogue with Morsi, instead. In addition, the White House only urged Morsi, as stated by Hauslohner (2013), to respond to the protesters' demands regarding democracy but not departure which represented their main demand and asked both Morsi's opponents and allies to stop violence and engage in dialogue. This exhibits the US' endorsement of Morsi and the MB. Though Obama avoided using the word coup to explicitly describe the military intervention, he threatened, as Alexander (2013) and Martin (2013) pinpointed, that such intervention could influence the US' annual financial aid to Egypt and demanded the military to stop arbitrary detentions of Morsi and his backers.

As for the UK, Cameron and Hague stated that they denounced military involvement in democracies (Alexander, 2013; Martin, 2013). 
Hence, they were dissatisfied with the Egyptian military takeover though they did not overtly name it a coup. However, they said they would work with the new Egyptian government only to safeguard the British interests in Egypt (Alexander, 2013; Martin, 2013). In fact, both the US' and UK's official mainstream ideological views could interpret the investigated Western newspapers' bias against the June 30 protests.

\section{Conclusion}

The two research questions (see Section 3) were addressed by analyzing naming and predication and their creation of biased classification schemes through Fairclough's (1995a) description stage, by underpinning the relationship between text in this respect and interaction through his interpretation stage via highlighting van Dijk's (1995d, 2000) Us/Them dichotomy, and finally by underscoring the relationship between the ideological references revealed in the second stage and the social context through his explanation stage. Such a three-stage analysis provided the findings below.

The present study emphasized that differences in expression, as held by Fairclough (1989), Fowler (1991), Reisigl and Wodak (2001), and Richardson (2007), carry ideological discrepancies and reveal representations of power, as manifested in the naming and predication employed in the examined newspapers' coverage of both protests. Such textual features helped generate biased classification schemes that revealed, as believed by Fairclough (1989), each examined newspaper's preoccupation with particular aspects of reality. Accordingly, these schemes demonstrated the (de-)legitimization of both protests in the American and British press (see Section 7.1). The examined newspapers manipulated the investigated textual features to represent their ideological perspectives on both Egyptian protests. This lends support to the idea that the language used to represent the world is not value-free or coincidental and there are power relations underlying it, as believed by the CDA scholars (e.g. Blommaert \& Bulcaen, 2000; Fairclough, 1989, 1992, 1993, 1995a; Fairclough \& Wodak, 1997; Hodge \& Kress, 1993; Huckin, 2002; van Dijk, 1980, 1983, 1991, 1993b, 1995a, 1995b, 1996, 1997, 2001; Wodak, 1996). 
The analysis of naming and predication and the resultant classification schemes in the present study demonstrated the Western newspapers' constant support for the anti-Mubarak protests and bias against the anti-Morsi protests. The analysis of the aforestated textual features led to uncovering the examined newspapers' dichotomous Us/Them model in their coverage of both protests through the help of van Dijk's (2000) ideological square, which underscores that their coverage was ideologically biased. This highlights the subjectivity of the news reporting discourse; such discourse contains values, attitudes, and ideas, not mere facts (Cotter, 2010; Fairclough, 1994, 2003; Fowler, 1991; Hodge \& Kress, 1993; Richardson, 2007; van Dijk, 1988, 1991, 1993a, 1998).

It can be noted that both examined Western newspapers legitimized the anti-Mubarak protests from its very onset and called it a revolution to show that such protests were aiming at changing authority; however, no violence was associated with them, lending support to the findings of both Guzman (2016) and Youssef (2012) in this respect. Besides, the protesters' violence was rationalized as a reaction to the regime's initiated aggression in line with Guzman's (2016) examined American news outlets. In addition, both newspapers provided some detailed description of the socio-political context that resulted in the protests which mainly lay in the people's dire need for economic and political reforms, emphasizing Guzman's (2016) and Youssef's (2012) description of the protests as a result of bad economy and democracy seeking . In contrast, both Western newspapers negatively presented the anti-Morsi protesters from the very beginning of the protests on Nov. 23, 2012 until his ouster on July 3 as obstacles on the way to democracy. This discredited their call for democracy and justice which, from their own perspective, would be achieved by Morsi's departure. These findings provide an answer to the first research question (see Section 3).

The present study, moreover, unveiled the power relations that shaped the January 25 and June 30 protests discourse in the examined newspapers. The study revealed that each newspaper's ideological stance towards both Egyptian protests was tremendously fed by its 
ownership/political affiliation, being mainstream elite media outlets, hence giving support to the notion of the media as an ISA in the sense of Althusser (1971). In fact, both examined Western newspapers demonstrated consistent reflection of the official mainstream ideological views during both investigated protests. These findings provide an answer to the second research question (see Section 3).

It is my hope that this study will open horizons for further CDA research on press discourse, especially news coverage of mass protests and revolutions in Egypt, regionally, and beyond. The study captured the similarities and differences that existed across American and British news outlets in their coverage of both Egyptian protests. Thus, its results could be an indication on how such media outlets covered both protests. However, only two out of many daily newspapers were selected for qualitative analysis, hence eliminating a possible range of alternative or matching voices in the media. Accordingly, examining a wider sample of newspapers is highly recommended in further studies including partisan and state-owned newspapers whether nationally or internationally, Middle East newspapers, and other European newspapers written in different languages. 


\section{References}

Abdul-Raof, H. (2001). Arabic stylistics: A coursebook. Wiesbaden: Otto Harrassowitz Verlag.

Adams, I. (2001). Political ideology today. Manchester: Manchester University Press. Alexander, H. (2013, July 4). World reaction to Egypt coup. The Telegraph. Retrieved from http://www.telegraph.co.uk/news/worldnews/africaandindianocean/egypt/10 159658/World-reaction-to-Egypt-coup.html

Aljazeera. (2011, February 14). Timeline: Egypt's revolution. Retrieved from http://www.aljazeera.com/news/middleeast/2011/01/201112515334871490.h $\underline{\mathrm{tml}}$

Althusser, L. (1971). Ideology and ideological state apparatuses: Notes towards an investigation. In L. Althusser (Ed.), Lenin and philosophy, and other essays (pp. 121-173). (B. Brewster, Trans). New York: Monthly Review Press.

Ansolabehere, S., Lessem, R., \& Snyder, J. (2004). The political orientation of newspaper endorsements in U.S. elections, 1940- 2002. Retrieved from https://www.andrew.cmu.edu/user/rlessem/endorse.pdf

Arabic Learning Resources. (2007). Egyptian Arabic insults and crude language. Retrieved from http://arabic.desert-sky.net/coll_insult.html

Ashley, L. \& Olson, B. (1998). Constructing reality: Print media's framing of the women's movement, 1966-1986. Journalism and Mass Communication, 75(2), 263-277.

Bell, A. (1991). The language of news media. Oxford: Blackwell.

Blommaert, J. (2005). Discourse: A critical introduction. Cambridge, UK: Cambridge University Press.

Blommaert, J. \& Bulcaen, C. (2000). Critical discourse analysis. Annual Review of Anthropology, 29, 447-466.

Brennan, A. (2012, October 27). The New York Times endorses Obama again. Retrieved from http://politicalticker.blogs.cnn.com/2012/10/27/the-newyork-times-endorses-obama-again/

Bubalo, A. (2012). Egypt's Islamist president: What lies ahead? Sydney: Lowy Institute For International Policy.

Chomsky, N. (1997, October). What makes mainstream media mainstream. Z Magazine. Retrieved from: http://www.chomsky.info/articles/199710--.htm

Chouliaraki, L. \& Fairclough, N. (1999). Discourse in late modernity: Rethinking critical discourse analysis. Edinburgh: Edinburgh University Press. 
Cotter, C. (2010). News talk: Investigating the language of journalism. New York, USA: Cambridge University Press.

Cottle, S. (2000). Rethinking news access. Journalism Studies, I(3), 427-448.

Dunlevy, M. (1998). Objectivity. In M. Breen (Ed.), Journalism: Theory and practice (pp. 119-138). Paddington, NSW: Macleay Press.

El-Nashar, M. M. M. (2014). Media bias: A critical discourse analysis of the representation of the Egyptian army in The New York Times. International Journal of Arts \& Sciences, 7(4), 265-292.

Fahim, K., Slackman, M., \& Rohde, D. (2011, February 6). Egypt's ire turns to confidant of Mubarak's son. The New York Times. Retrieved from

http://www.nytimes.com/2011/02/07/world/middleeast/07corruption.html?_r $\underline{\underline{0}}$

Fairclough, N. (1989).Language and power. London: Longman.

Fairclough, N. (1992). Discourse and social change. Cambridge: Polity Press.

Fairclough, N. (1993). Critical Discourse Analysis and the Marketization of Public Discourse: The Universities. Discourse \& Society, 4(2), 133-168.

Fairclough, N. (1994). Discourse and social change. Massachusetts: Polity Press.

Fairclough, N. (1995a). Critical discourse analysis: The critical study of language. London: Longman.

Fairclough, N. (1995b). Media discourse. London: Edward Arnold.

Fairclough, N. (2003). Analyzing discourse: Textual analysis for social research. London: Routledge.

Fairclough, N. (2006). Language and globalization. New York: Routledge.

Fairclough, N. \& Wodak, R. (1997). Critical discourse analysis. In T. A. van Dijk (Ed.), Discourse as social interaction. Discourse studies: A multidisciplinary introduction (pp. 258-284). London: Sage Publications.

Foreign and Commonwealth Office (2011, January 28). Foreign secretary on protests in Egypt. Retrieved from https://www.gov.uk/government/news/foreignsecretary-on-protests-in-egypt

Fowler, R. (1991). Language in the news: Discourse and ideology in the press. London: Routledge.

Fowler, R., Hodge, R., Kress, G., \& Trew, T. (1979). Language and control. London: Routledge and Kegan Paul.

Gitlin, T. (1980). The whole world is watching: Mass media in the making and unmaking of the new left. Berkeley, CA: University of California Press. 


\section{Hebatollah M. M. Hegazy}

Goodman, J. D. (2011, February 11). World Leaders Cheer but Remain Wary. The New York Times. Retrieved from http://www.nytimes.com/2011/02/12/world/middleeast/12global.html

Green, D. (2011, February 17). What caused the revolution in Egypt? The Guardian. Retrieved from

http://www.theguardian.com/global-development/povertymatters/2011/feb/17/whatcaused-egyptian-revolution

Guzman, A. L. (2016). Evolution of news frames during the 2011 Egyptian revolution: Critical discourse analysis of Fox News's and CNN's framing of protesters, Mubarak, and the Muslim Brotherhood. Journalism \& Mass Communication Quarterly, 93(1), 80-98.

Hauslohner, A. (2013, July 2). Egypt's Morsi defiant under pressure as deadline looms. The Washington Post. Retrieved from

http://www.washingtonpost.com/world/middle_east/2013/07/02/fcb11aa0-e31511e2-a11e-c2ea876a8f30_story.html

Herman, E. S. \& Chomsky, N. (2002). Manufacturing consent: The political economy of the mass media. London: Pantheon.

Hodge, R. \& Kress, G. (1993). Language as ideology. London: Routledge.

Holmes, A. A. (2012). There are weeks when decades happen: Structure and strategy in the Egyptian revolution. Mobilization: An International Journal, 17(4), 391-410.

Huckin, T. (2002). Critical discourse analysis and the discourse of condescension. In E. Barton \& G. Stygall (Eds.), Discourse studies in composition. Hampton: University of Utah. Retrieved from

http://www.writing.ucsb.edu/wrconf08/Pdf_Articles/Huckin_Article.pdf

Ibrahim, R. (2013, June 25). Obama to Egyptian Christians: Don't protest the Brotherhood. FrontPage MAG. Retrieved from www.frontpagemag.com/2013/raymound-ibrahim/u-s-asks-egyptschristians-not-to-oppose-morsi/

Iggers, J. (1999). Good news, bad news: Journalism ethics and the public interest. Boulder: Westview Press.

Klaehn, J. (2010). The political economy of media and power. New York: Peter Lang. Lawrence, R. (2000). The politics of force: Media and the construction of police brutality. Berkeley: University of California Press.

Longman Dictionary of Contemporary English Online. (2015). Retrieved June, 2017, from http://www.ldoceonline.com/ 
Manning, P. (2001). News sources: A critical introduction. London: Routledge.

Martin, D. (2013, July 5). We'll work with regime, says Hague: Foreign Secretary says Britain does not support Egypt's military intervention and coup was 'dangerous thing'. The Daily Mail. Retrieved from http://www.dailymail.co.uk/news/article-2356534/William-Hague-says-

Britain-does-support-Egypts-military-intervention-coup-dangerousthing.html

McLeod, D. M. (1995). Communicating deviance: The effects of television news coverage of social protest. Journal of Broadcasting and Electronic Media, 39(1), 4-19.

McLeod, D. M. \& Hertog, J. K. (1992). The manufacture of public opinion for reporters: Informal cues for public perceptions of protest groups. Discourse \& Society, 3 (3), 259-275.

McQuail, D. (1993). Media performance: Mass communication and the public interest. London: Sage.

Merriam-Webster. (2015). Retrieved April, 2017, from http://www.merriamwebster.com/

Molotch, H. \& Lester, M. (1974). News as purposive behavior: On the strategic use of routine events, accidents, and scandals. American Sociological Review, 39, 101-112.

Murdock, G. (2000). Reconstructing the ruined tower: Contemporary communications and questions of class. In J. Curran \& M. Gurevitch (Eds.), Mass media and society (pp. 7-26). London: Arnold.

Okrent, D. (2004, July 25). The public editor; Is The New York Times a liberal newspaper? The New York Times. Retrieved from http://www.nytimes.com/2004/07/25/opinion/the-public-editor-is-the-newyork-times-a-liberal-newspaper.html

Oxford Learner's Dictionaries. (2015). Retrieved January, 2017, from http://www.oxfordlearnersdictionaries.com/

Reisigl, M. \& Wodak, R. (2001). Discourse and discrimination: Rhetorics of racism and anti-semitism. London: Routledge.

Richardson, J. E. (2006). Who gets to speak? A study of sources in the broadsheet press. In E. Poole \& J. E. Richardson (Eds.), Muslims and the news media (pp. 103-115). London: I.B. Tauris. 


\section{Hebatollah M. M. Hegazy}

Richardson, J. E. (2007). Analyzing newspapers: An approach from critical discourse analysis. New York: Palgrave Macmillan.

Rogers, R. (2004). An introduction to critical discourse analysis in education. London: L. Erlbaum Associates.

Ross, T., Moore, M., \& Swinford, S. (2011, January 28). Egypt protests: America's secret backing for rebel leaders behind uprising. The Telegraph. Retrieved from

http://www.telegraph.co.uk/news/worldnews/africaandindianocean/egypt/82

89686/Egypt-protests-Americas-secret-backing-for-rebel-leaders-behinduprising.html

Sharp, J. M. (2013). Egypt: Background and U.S. relations. Congressional Research Service, 1-18. Retrieved from

https://digital.library.unt.edu/ark:/67531/metadc306543/m1/1/high_res_d/RL33003_2 014Jun05.pdf

Slate. (2013, April 5). The Associated Press's new definition of "Islamists". Retrieved from www.slate.com/blogs/ the_slatest/2013/04/05/_islamist_definition_changed _in_the_ap_stylebook_two_days_after_illegal.html

Tuchman, G. (1978). Making news: A study in the construction of reality. London: Free Press; Collier Macmillan.

van Dijk, T. A. (1980). Macrostructures: An interdisciplinary study of global structures in discourse, interaction and cognition. Hillsdale, New Jersey: Lawrence Erlbaum Associates Publishers.

van Dijk, T. A. (1983). Discourse analysis: Its development and application to the structure of news. Journal of Communication, 33, 20-43.

van Dijk, T. A. (1988). News as discourse. New Jersey \& London: Lawrence Erlbaum Associates Publishers.

van Dijk, T. A. (1991). Racism and the press. London: Routledge.

van Dijk, T. A. (1993a). Elite discourse and racism. London: Sage Publications.

van Dijk, T. A. (1993b). Principles of critical discourse analysis. Discourse and Society, 4(2), 249-283.

van Dijk, T. A. (1995a). Aims of critical discourse analysis. Japanese Discourse, 1, 17-27.

van Dijk, T. A. (1995b). Discourse semantics and ideology. In C. Schaffner \& A. Wendem (Eds.), Language and peace (pp. 17-40). London: Sage. 
van Dijk, T. A. (1996). Discourse, opinions and ideologies. In C. Schaffner \& H. Kelly-Holmes (Eds.), Discourse and ideologies (pp. 7-37). Clevedon: Multilingual Matters Ltd.

van Dijk, T. A. (1997). Discourse as interaction in society. In van Dijk, T. A. (Ed.). Discourse as social interaction. Discourse studies: A multidisciplinary introduction (pp. 1-40). London: Sage Publications.

van Dijk, T. A. (1998). Opinions and ideologies in the press. In A. Bell \& P. Garrett (Eds.), Approaches to media discourse (pp. 21-36). Oxford: Blackwell.

van Dijk, T. A. (2000). Ideology: A multidisciplinary approach. London: Sage Publications.

van Dijk, T. A. (2001). Critical discourse analysis. In D. Tannen, D. Schiffrin \& H. Hamilton (Eds.), Handbook of discourse analysis (pp. 352-371). Oxford: Blackwell.

van Ginneken, J. (2002). Global news: A critical introduction. London: Sage.

Wayne. M. (2003). Marxism and media studies: Key concerns and contemporary trends. London: Pluto Press.

Wodak, R. (1996). Disorders of discourse. London: Longman.

Youssef, A. (2012). A critical analysis on media coverage of the Egyptian revolution: The case of Al-Ahram, Al-Masry Al-Youm, The Telegraph and The Washington Post (MA thesis). Örebro University, Sweden. Retrieved from http://www.diva-portal.org/smash/get/diva2:540808/FULLTEXT01.pdf

Zaher, A. (2009). A critical discourse analysis of news reports on the Israeli/Palestinian conflict in selected Arab and Western newspapers (Doctoral dissertation). Nottingham Trent University, UK. Retrieved from irep.ntu.ac.uk./id/eprint/146/ 
Hebatollah M. M. Hegazy

\begin{tabular}{|c|c|c|}
\hline & $\begin{array}{c}\text { The New York Time } \\
\text { https://www.nytimes.com/ }\end{array}$ & $\begin{array}{c}\text { The Guardian } \\
\text { https://www.theguardian.com/international }\end{array}$ \\
\hline \multicolumn{3}{|c|}{ Event: The Day of Anger on Jan. 25, 2011} \\
\hline Headline & $\begin{array}{l}\text { Violent Clashes Mark Protests Against Mubarak's } \\
\text { Rule }\end{array}$ & Cairo protesters in violent clashes with police \\
\hline Report Length & words: $1363 \quad$ lines: 107 & words: 1124 \\
\hline Publishing Date & Jan. 25, 2011 & Jan. 26, 2011 \\
\hline \multicolumn{3}{|c|}{ Event: The Friday of Anger on Jan. 28, 2011} \\
\hline Headline & $\begin{array}{l}\text { Egyptian Hopes Converged in Fight for Cairo } \\
\text { Bridge }\end{array}$ & Egypt protesters defy curfew as tanks roll into Cairo \\
\hline Report Length & words: $964 \quad$ lines: 69 & words: 870 \\
\hline Publishing Date & Jan. 28, $2011 \quad$ (a) & Jan. 28, 2011 $\quad$ (a) \\
\hline Headline & $\begin{array}{l}\text { Mubarak Orders Crackdown, With Revolt } \\
\text { Sweeping Egypt }\end{array}$ & $\begin{array}{l}\text { Egypt's day of fury: Cairo in flames as } \\
\text { cities become battlegrounds }\end{array}$ \\
\hline Report Length & words: 1629 lines: 125 & words: 1310 \\
\hline Publishing Date & Jan. 28, 2011 & Jan. 28, 2011 \\
\hline \multicolumn{3}{|c|}{ Event: The Battle of the Camel on Feb. 2, 2011 } \\
\hline Headline & Mubarak's Allies and Foes Clash in Egypt & Egypt's revolution turns ugly as Mubarak fights back \\
\hline Report Length & words: $1469 \quad$ lines: 115 & words: $911 \quad$ lines: 69 \\
\hline Publishing Date & Feb. 2, 2011 $\quad$ (a) & Feb. 2, 2011 $\quad$ (a) \\
\hline Headline & Street Battle Over the Arab Future & $\begin{array}{l}\text { Mubarak supporters fight to take over Egypt's Tahrir } \\
\text { Square }\end{array}$ \\
\hline Report Length & words: 1175 & words: 1237 \\
\hline Publishing Date & Feb. 2, 2011 $\quad$ (b) & Feb. 2, 2011 $\quad$ (b) \\
\hline \multicolumn{3}{|c|}{ Event: The Largest Million-Men Demonstration on Feb. 8, 2011 During the Resistance Week } \\
\hline Headline & $\begin{array}{l}\text { As Egypt Protest Swells, U.S. Sends Specific } \\
\text { Demands }\end{array}$ & $\begin{array}{l}\text { Egyptians renew appeal for Mubarak to resign now on } \\
\text { biggest day of protest }\end{array}$ \\
\hline Report Length & words: $1253 \quad$ lines: 97 & words: 1165 \\
\hline Publishing Date & Feb. 8, 2011 & Feb. 8, 2011 \\
\hline \multicolumn{3}{|c|}{$\begin{array}{c}\text { Event: Mubarak's Resignation on Feb. 11, } 2011 \\
\end{array}$} \\
\hline Headline & Egypt Erupts in Jubilation as Mubarak Steps Down & $\begin{array}{ll}\text { IV. } & \text { Fury in Egypt as Mubarak refuses to } \\
\text { leave } & \end{array}$ \\
\hline
\end{tabular}


A Critical Discourse Analysis of Naming and Predication in Western News Coverage of the Egyptian January 25 and June 30 Protests

\begin{tabular}{|c|c|c|}
\hline Report Length & words: 1891 & words: 992 \\
\hline Publishing Date & Feb. 11, 2011 & Feb. 11, 2011 \\
\hline Headline & World Leaders Cheer but Remain Wary & $\begin{array}{l}\text { Hosni Mubarak resigns - and Egypt celebrates a new } \\
\text { dawn }\end{array}$ \\
\hline Report Length & words: 724 & words: $1202 \quad$ lines: 77 \\
\hline Publishing Date & Feb. 11, 2011 & Feb. 11, 2011 \\
\hline $\begin{array}{l}\text { Total No. of } \\
\text { Words \& Lines }\end{array}$ & 10468 & 8811 \\
\hline Overall No. & Words: 19279 (both newspapers) & Lines: 1432 (both newspapers) \\
\hline
\end{tabular}




\section{Hebatollah M. M. Hegazy}

\section{Appendix B: Collected Data on the Egyptian June 30 Protests}

\begin{tabular}{|c|c|c|}
\hline & $\begin{array}{c}\text { The New York Time } \\
\text { https://www.nytimes.com/ }\end{array}$ & $\begin{array}{c}\text { The Guardian } \\
\text { https://www.theguardian.com/international }\end{array}$ \\
\hline \multicolumn{3}{|c|}{ Event: Morsi's Constitutional Declaration on Nov. 22 \& The First Anti-Regime Protests on Nov. 23, 2012} \\
\hline Headline & $\begin{array}{l}\text { Citing Deadlock, Egypt's Leader Seizes New Power } \\
\text { and Plans Mubarak Retrial }\end{array}$ & $\begin{array}{l}\text { Mohamed Morsi bars court challenges and orders Hosni } \\
\text { Mubarak retrial }\end{array}$ \\
\hline Report Length & words: $968 \quad$ lines: 74 & words: $\mathbf{1 0 3 8} \quad$ lines: 77 \\
\hline Publishing Date & Nov. 22, 2012 & Nov. 22, 2012 \\
\hline Headline & $\begin{array}{l}\text { Clashes Break Out After Morsi Seizes New Power in } \\
\text { Egypt }\end{array}$ & Protests erupt across Egypt after presidential decree \\
\hline Report Length & words: $1260 \quad$ lines: 95 & words: 1368 \\
\hline Publishing Date & Nov. 23, 2012 & Nov. 23, 2012 \\
\hline \multicolumn{3}{|c|}{$\begin{array}{c}\text { Event: Approving Egypt's Post-Revolution Draft Constitution on Nov. } 29 \text { \& The Violent Clashes Between Anti-and Pro-Morsi } \\
\text { Camps on Dec. 5, 2012 }\end{array}$} \\
\hline Headline & $\begin{array}{l}\text { Egyptian Islamists Approve Draft Constitution } \\
\text { Despite Objections }\end{array}$ & $\begin{array}{l}\text { Egyptian assembly expected to approve draft } \\
\text { constitution }\end{array}$ \\
\hline Report Length & words: $1057 \quad$ lines: 84 & words: $497 \quad$ lines: 37 \\
\hline Publishing Date & Nov. 29, 2012 & Nov. 29, 2012 \\
\hline Headline & $\begin{array}{l}\text { Blood Is Shed as Egyptian President's Backers and } \\
\text { Rivals Battle in Cairo }\end{array}$ & $\begin{array}{l}\text { Morsi supporters clash with protesters outside } \\
\text { presidential palace in Cairo }\end{array}$ \\
\hline Report Length & words: $1303 \quad$ lines: 100 & words: $747 \quad$ lines: 57 \\
\hline Publishing Date & Dec. 5, 2012 & Dec. 5, 2012 \\
\hline \multicolumn{3}{|c|}{ Event: June 30 Anti-Morsi Mega Protests on June 30, 2013} \\
\hline Headline & By the Millions, Egyptians Seek Morsi's Ouster & Protesters across Egypt call for Mohamed Morsi to go \\
\hline Report Length & words: $1381 \quad$ lines: 98 & words: $1647 \quad$ lines: 121 \\
\hline Publishing Date & June 30, 2013 & June 30, 2013 \\
\hline \multicolumn{3}{|c|}{ Event: The Military's 48-Hour Ultimatum on July 1, 2013} \\
\hline Headline & $\begin{array}{l}\text { Morsi Faces Ultimatum as Allies Speak of Military } \\
\text { 'Coup' }\end{array}$ & Egypt's presidency defies threat of military coup \\
\hline Report Length & words: $1544 \quad$ lines: 111 & words: 335 \\
\hline Publishing Date & July 1, 2013 & July 1, 2013 \\
\hline \multicolumn{3}{|c|}{ Event: Morsi's Ouster on July 3, 2013 } \\
\hline Headline & $\begin{array}{l}\text { Army Ousts Egypt's President; Morsi Is Taken Into } \\
\text { Military Custody }\end{array}$ & $\begin{array}{ll}\text { المقالة VI. } & \text { Egypt: President Morsi defiant as army } \\
\text { deadline runs out } & \end{array}$ \\
\hline
\end{tabular}


A Critical Discourse Analysis of Naming and Predication in Western News Coverage of the Egyptian January 25 and June 30 Protests

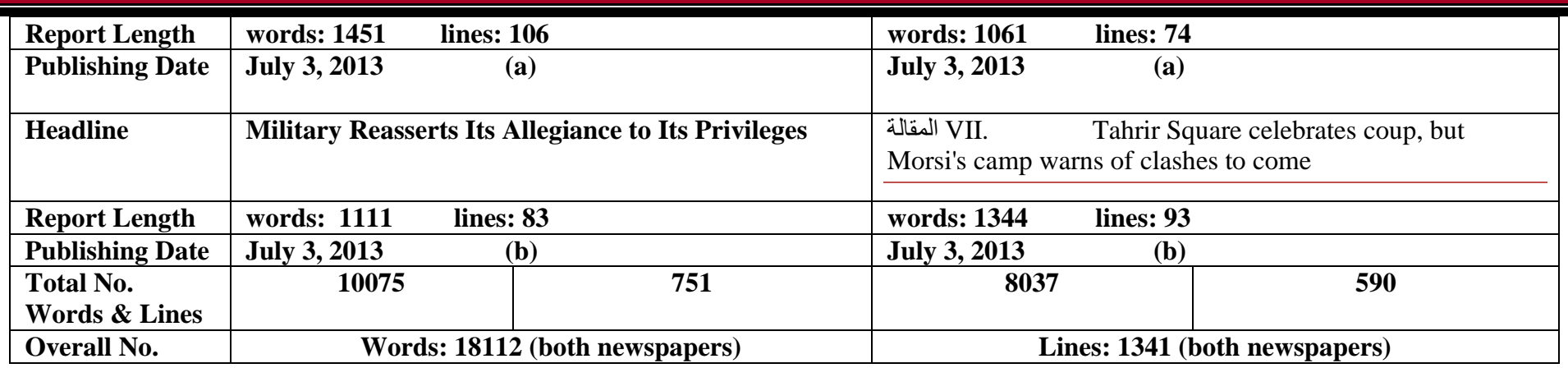

